\title{
AN EXPANDED ROLE FOR IN VITRO SYMBIOTIC SEED GERMINATION AS A CONSERVATION TOOL: TWO CASE STUDIES IN NORTH AMERICA (PLATANTHERA LEUCOPHAEA AND EPIDENDRUM NOCTURNUM)
}

\author{
EMily E. MASSEY \& LAWRenCE W. ZetTLER ${ }^{1}$ \\ Orchid Recovery Program, Illinois College \\ 1101 West College Avenue, Jacksonville, Illinois 62650 USA \\ 'Author for correspondence: 1wzettle@ic.edu
}

KEY WoRDS: mycorrhizal fungi, symbiotic germination, Orchidaceae, Platanthera, Epidendrum

Interest in using mycorrhizal fungi to cultivate orchids from seed in vitro (=symbiotic seed germination) has intensified in recent years and this approach is now an important conservation tool worldwide. In North America, symbiotic germination has been attempted for a growing number of orchid species in peril as a means to acquire seedlings suitable for reintroduction. Several taxa have proven surprisingly easy to cultivate in this manner to a leaf-bearing stage, including terrestrials and epiphytes alike (Table 1), and a few have been reintroduced with success. Some, however, have been more problematic. For example, the prairie-fringed orchids of the Midwest (Platanthera leucophaea (Nuttall) Lindl. and P. praeclara Sheviak \& Bowles) require cold-moist stratification to prompt seed germination and development resulting in leaf-bearing seedlings (Zettler et al. 2001, 2005; Sharma et al. 2003), but seedling survival ex vitro has not been achieved. A few species have resisted symbiotic germination altogether despite vigorous attempts (e.g., Isotria medeoloides (Pursh.) Raf., Zettler unpubl. data) and may be candidates for alternative techniques (e.g., asymbiotic germination) exemplified by the hardy lady's slipper orchids (genus Cypripedium) which have been cultured without fungi.

Although modest progress continues, most of the remaining 200+ species native to the United States and Canada still remain vulnerable because so few have been propagated from seed, with or without fungi. In light of ongoing habitat loss and other ecological concerns (e.g., global warming), it seems likely that a significant number of species will face imminent extinction this century unless conservation efforts are swiftly expanded and rendered more effective. Thus far, symbiotic germination does show promise as an effective conservation tool in North America, especially if it is applied within the framework of integrated and responsible conservation practices that continue to be developed here (e.g., Stewart 2003) and overseas (e.g., Batty et al. 2006a, 2006b). Recently, questions concerning the ethics of releasing fungus-infected seedlings "ad hoc" have been raised. For example, the release of laboratory-grown seedlings into the natural habitat has the potential to alter the gene pool of the resident orchid, assuming that such seedlings eventually initiate anthesis (Zettler 2005). Moreover, if the fungus that was utilized in vitro originated from a different geographical area or habitat, the act of releasing such a fungus could alter the delicate ecosystem already in place (Zettler 2005). If true, reintroducing orchid seedlings in the "spirit" of conservation could, in fact, prove detrimental. Consequently, the recovery and use of fungi from the original habitat seems preferable to using fungi from distant geographical areas and from different host orchids, except in unusual instances (see Zettler et al. 2006 for Platanthera holochila in Hawaii).

Gaining an understanding of the fungal associates in situ and their role on the orchid life cycle is crucial, and is an important conservation objective for a number of rare North American orchids (e.g., Platanthera leucophaea; Bowles \& Bell 1999). In nature, orchid protocorms, seedlings and mature plants are assumed to associate mostly with higher fungi, especially members of the Phylum Basidiomycota (= club fungi or basidiomycetes), based on standard fungal isolation techniques (e.g., Currah et al. 1997) and direct PCR amplification of fungal genes from orchid tissues (e.g., Shefferson et al. 2005). Orchids also associate with members of the Phylum Ascomycota (= sac fungi or ascomycetes), conidial fungi (= "Fungi Imperfecti" or 
molds), and vesicular-arbuscular mycorrhiza (Currah et al. 1997), but the extent of their physiological role(s) is uncertain. Currah et al. (1997) suggested that some of the ascomycete and mold associates - largely discounted by researchers - may actually be equally important to orchids in situ because of their nutrient-gathering and sequestering roles. Thus, a wider range of fungal groups may be at play within the greater rhizosphere than simply those that form distinctive intracellular pelotons (i.e., the basidiomycetes). Until reliable protocols can be developed to ascertain the role(s) of these seemingly less important fungal groups, current emphasis will remain on the peloton-forming fungi. During the past decade, the role of in vitro symbiotic germination has expanded beyond simple propagation. Many researchers now utilize in vitro symbiotic germination as a tool to augment molecular studies by verifying the mycorrhizal nature of the fungi identified. As more orchid taxa are studied in this manner and over a wider geographical area, the natural distribution and identity of the physiologically significant fungal strains becomes more apparent. Such data are invaluable at answering questions aimed at fungal specificity and orchid distribution - both of which play a vital role in fostering effective orchid conservation. In vitro symbiotic germination also continues to have a useful role in answering questions aimed at fundamental orchid biology. The "closed system" or microcosm offered by a Petri plate, agar medium, and fungus allows for careful manipulation of the factors that influence seeds and seedlings (e.g., light pretreatment, substrate $\mathrm{pH}$, seed stratification). Such experimental outcomes have the potential to benefit conservation by improving germination and seedling survival, exemplified by previous studies (e.g., Rasmussen et al. 1989, 1990). During the past five years, another use for in vitro symbiotic germination has surfaced in North America that links the practice with cross pollination, and is discussed here further as a case study.

Case Study 1: Crossing Effects on Seed Viability, Germination, and Protocorm Growth of the Eastern Prairie Fringed Orchid (Platanthera LEUCOPHAEA). The U.S. Federal threatened eastern prairie fringed orchid, Platanthera leucophaea (Nutt.) Lindl., is a perennial, terrestrial species endemic to tallgrass prairie remnants and wetlands of the Midwest, and eastward into bogs and fens (Bowles 1983, Sheviak 1974, Sheviak \& Bowles 1986). Historical records indicate the species has suffered a $70 \%$ decline largely due to the conversion of its habitat to agriculture. Most of the remaining populations are small and fragmented. Given that the species utilizes a facultative breeding system (outcrossing) facilitated by hawkmoth pollination (Bowles et al. 2002), small, fragmented populations a fraction of their former size are suspected of contributing to low genetic diversity and inbreeding depression within existing sites. Individual plants typically flower once and are probably short-lived ( $<10$ years). In situ, the species utilizes mycorrhizal fungi assignable to the anamorphic genus Ceratorhiza (teleomorphs $=$ Ceratobasidium) throughout its life cycle (Zettler et al. 2005). Efforts to propagate P. leucophaea from seed to a leaf-bearing stage via symbiotic germination have been successful in vitro after seeds are pre-treated with cold-moist conditions (stratification) and subsequently inoculated with Ceratorhiza strains (Zettler et al. 2001, 2005). The development of a reliable protocol to propagate $P$. leucophaea from seed with fungi prompted a study to assess how different modes of pollination affect seed viability, germination, and seedling development. This project, conducted in collaboration with Timothy J. Bell (Chicago State University) and Marlin L. Bowles (The Morton Arboretum), is part of a series of studies aimed at eventually broadening the distribution of the species statewide (Illinois). The objective was to determine whether inbreeding and outbreeding depression (dilution of genes associated with local adaptation; disruption of co-adapted gene complexes) occur in P. leucophaea, with the ultimate goal of increasing the number of viable populations throughout its range. Crossing experiments took place during two flowering seasons $(2000,2002)$. In 2000, plants from three populations, separated by $>150 \mathrm{~km}$, were experimentally pollinated by hand. In 2002 , the experiment was repeated using populations separated by $>300 \mathrm{~km}$. Three types of crosses were carried out: self-pollinated (S), pollen transferred to other plants within the same population (out-crossed within, OW), and pollen transferred to other plants in distant populations (out-crossed between, $\mathrm{OB}$ ). The resulting seed was collected from mature, yellowing, indehiscent capsules, dried over $\mathrm{CaSO}_{4}$ desiccant, and subjected to cold-moist stratification $\left(6^{\mathrm{O}} \mathrm{C}\right)$ lasting $>3$ months. 
TABLE 1. Examples of endangered, threatened or otherwise uncommon North American orchids cultivated using the symbiotic technique. Terrestrial and epiphytic species are denoted by $(t)$ and $(e)$, respectively.

\begin{tabular}{|c|c|}
\hline Species & Notes \\
\hline Bletia urbana Dressler (t) & $\begin{array}{l}\text { Mexican endemic; seedlings reintroduced (Ortega-Larrocea } \\
\text { 2005) }\end{array}$ \\
\hline Cyrtopodium punctatum (L.) Lindl. (e) & Seedlings reintroduced (S.L. Stewart, unpubl. data) \\
\hline $\begin{array}{l}\text { Dichromanthus aurantiacus (t) } \\
\quad \text { (La Llave \& Lex.) Sal. \& Soto Arenas }\end{array}$ & Seedlings reintroduced (Rangel Villafranco 2006) \\
\hline Epidendrum nocturnum Jacquin (e) & Seedlings reintroduced (Zettler et al. 2006) \\
\hline Habenaria macroceratitis Willdenow (t) & Seedlings reintroduced (Poulter et al. 2005) \\
\hline Platanthera holochila (Hbd.) Krzl. (t) & $\begin{array}{l}\text { Hawaiian endemic, U.S. Federal Endangered; leaf-bearing } \\
\text { seedlings obtained in vitro, high seedling mortality ex vitro } \\
\text { (McDonald et al. 2006, L.W. Zettler unpubl. data) }\end{array}$ \\
\hline P. integrilabia (Correll) Luer $(\mathrm{t})$ & Seedlings established ex vitro (Zettler \& McInnis 1992) \\
\hline P. leucophaea (Nuttall) Lindl. (t) & $\begin{array}{l}\text { U.S. Federal Threatened; seedlings reintroduced with poor } \\
\text { survival (Zettler } \text { et al. 2005, L.W. Zettler unpubl. data) }\end{array}$ \\
\hline P. praeclara Sheviak \& Bowles (t) & $\begin{array}{l}\text { U.S. Federal Threatened; leaf-bearing seedlings obtained in } \\
\text { vitro (Sharma et al. 2003) }\end{array}$ \\
\hline Spiranthes brevilabris Lindl. (t) & $\begin{array}{l}\text { Seedlings reintroduced; anthesis }<7 \text { months (Stewart et al. } \\
\text { 2003) }\end{array}$ \\
\hline S. longilabris Lindl. (t) & $\begin{array}{l}\text { Seedlings reintroduced (L.W. Zettler \& K.A. Piskin unpubl. } \\
\text { data) }\end{array}$ \\
\hline
\end{tabular}

Seeds were sown in vitro on an oat-based medium and inoculated with mycorrhizal fungi (Ceratorhiza goodyerae-repentis Constantin \& Dufour) previously recovered from $P$. leucophaea tissues. Seed viability in both years was significantly lower for $\mathrm{S}$ progeny, but there was no significant difference between $\mathrm{OW}$ and $\mathrm{OB}$ progeny. Percent seed germination was significantly lower for S, but did not differ between OW and OB. These results, albeit preliminary, indicate that starting a new population of $P$. leucophaea from seed should not be detrimental. Although the effects of outbreeding depression may not appear for several generations, it is reasonable to assume that larger distances $(>1000 \mathrm{~km})$ are needed for this to occur.

Although symbiotic germination has been applied mostly to temperate terrestrial orchids like $P$. leucophaea, it may also have practical merit for epiphytic species. Epiphytic orchids have long been suspected of being less dependent on mycorrhizal fungi than their terrestrial counterparts, especially at maturity. This may explain, in part, why these plants are less problematic to cultivate from seed in the absence of mycorrhizal fungi (asymbiotic germination). Nevertheless, it is reasonable to assume that epiphytic orchids utilize fungi to some degree to prompt seedling development in situ, and evidence now suggests that fungi also provide these plants with a critical source of free water to resist desiccation on arboreal substrates (Yoder et al. 2000). Thus, efforts aimed at epiphytic orchid conservation should take into account the potential significant role(s) of such fungi, and act accordingly. This was the impetus of the second case study summarized below and published recently (Zettler et al. 2006).

\section{CASE STUDY 2: PROPAGATION OF AN EPIPHYTIC ORCHID (EPIDENDRUM NOCTURNUM) WITH A MYCORRHIZAL FUNGUS.}

The genus Epidendrum contains ca. 2000 neotropical species, many of which produce appealing floral displays suitable for horticulture. Epidendrum nocturnum is no exception. In south Florida, showy epiphytic orchids like E. nocturnum have been targeted by poachers leading to legendary stories that have resulted in best-selling novels and at least one movie 
TABLE 2. Examples of North American orchid taxa cultivated to the leaf-bearing stage with mycorrhizal fungus strain UAMH 9824 (Epulorhiza repens (Bernard) Moore). Terrestrial and epiphytic species are denoted by ( $t$ ) and (e), respectively.

\begin{tabular}{|c|c|}
\hline Species & Notes \\
\hline Cyrtopodium punctatum (L.) Lindl. (e) & S.L. Stewart et al. unpubl. data \\
\hline Epidendrum nocturnum Jacquin (e) & Zettler et al. 2006 \\
\hline H. macroceratitis Willdenow (t) & $\begin{array}{l}\text { Stewart \& Zettler 2002, Stewart \& Kane 2006a, } \\
\text { Poulter } \text { et al. } 2005\end{array}$ \\
\hline H. odontopetala Reichenbach (t) & S.L. Stewart unpubl. data \\
\hline H. repens Nuttall (t) & Stewart \& Zettler 2002 \\
\hline Piperia unaluscensis (Sprengel) Ryd. (t) & S.L. Stewart unpubl. data \\
\hline Platanthera ciliaris (L.) Lindl. (t) & Hartsock et al. 2003 \\
\hline P. holochila (Hbd.) Krzl. (t) & Zettler et al. 2005 \\
\hline Spiranthes brevilabris Lindl. (t) & Stewart et al. 2003, Stewart \& Kane 2006b \\
\hline S. cernua (L.) Rich. (Florida race) (t) & S. L. Stewart unpubl. data \\
\hline S. delitescens Sheviak (t) & A.J. Hicks unpubl. data \\
\hline S. longilabris Lindl. (t) & L.W. Zettler \& K.A. Piskin unpubl. data \\
\hline S. magnicamporum Sheviak (t) & listed as S. cernua in Wagoner et al. 2002 \\
\hline S. odorata (Nuttall) Lindl. (t) & S.L. Stewart unpubl. data \\
\hline
\end{tabular}

(“Adaptation"). In addition, these plants are also threatened by exotic species, habitat loss, and natural disasters (e.g., Hurricane Wilma in 2005). To facilitate their conservation, a project was initiated at Illinois College to cultivate several noteworthy taxa from south Florida in collaboration with Scott L. Stewart (University of Florida's Plant Restoration, Conservation, and Propagation Biotechnology Program) and Larry Richardson (Florida Panther National Wildlife Refuge). Given the successful application of symbiotic germination to terrestrial orchids in North America, the technique was applied to $E$. nocturnum to determine if epiphytic orchids could also be cultivated with fungi. Seeds were obtained from mature capsules at two locations in Collier Co., Florida (Fakahatchee Strand, Florida Panther NWR), promptly dried over $\mathrm{CaSO}_{4}$ desiccant, and stored at $-7^{\circ} \mathrm{C}$ for $1-2$ years. Seeds were sown on two types of oat-based media and inoculated with the ubiquitous mycorrhizal fungus, Epulorhiza repens (Bernard) Moore. The strain of $E$. repens (UAMH 9824; Sbrev-266) originated from Florida where it was isolated from the roots of a terrestrial orchid, Spiranthes brevilabris Lindley (Stewart et al., 2003). This fungus was chosen because of its marked ability to prompt seedling development in numerous other taxa (Table 2).

Seed germination commenced within 21 days of sowing and inoculation.

Significant differences in germination were detected between the two seed sources. After 48 days in vitro, leaf-bearing seeds were transferred to greenhouse conditions ex vitro and placed on pre-sterilized Sphagnum moss soaked with or without half-strength commercial fertilizer. After 163 days ex vitro, higher seedling survivorship (>90\%) occurred on Sphagnum lacking the fertilizer. Seedlings originating from a nutrient medium (modified oats medium, MOM; Clements et al., 1986) experienced much higher survivorship on Sphagnum containing fertilizer $(86 \%)$ than seedlings arising from a medium lacking nutrients (44\%). Thus, seedlings exposed to nutrients early in their development may have acclimated to the commercial fertilizer ex vitro. Pelotons were observed in roots of selected seedlings suggesting that they had a mycotrophic capability, but were infrequent. Seedlings were reintroduced into the Florida Panther NWR 16 months after sowing. Few of 
the seedlings survived in situ after one year. Efforts are underway to increase survivorship following reintroduction by timing their release with the onset of the rainy season. Although it appears that symbiotic germination may have practical merit for the conservation of E. nocturnum and possibly other rare epiphytic orchids, care should be exercised when selecting fungi for this purpose. The fungus species utilized in this study ( $E$. repens) is considered a common associate of orchids worldwide, but this particular strain (UAMH 9824) may not be because it was isolated in the northern part of the state (Levy Co., Florida). The decision to use this strain was based on its general geographic origin (Florida), but future, similar studies should utilize fungi from the same habitat if available. Efforts to recover fungi from wild populations of E. nocturnum in south Florida have, so far, been unsuccessful.

Recently (August, 2006) efforts have been underway to cultivate at least four other rare orchids from south Florida using both symbiotic and asymbiotic germination: Epidendrum amphistomum A. Richard, E. rigidum Jacquin, Polystachya concreta (Jacquin) Garay $\&$ Sweet and Vanilla phaeantha Reichenbach. Thus far, E. amphistomum and $P$. concreta have been cultured to the leaf-bearing stage in vitro on asymbiotic media alone. Seeds of $V$. phaeantha have resisted all treatments and media - perhaps typical for the genus. In nature, Vanilla capsules may be consumed and seeds dispersed by invertebrates and vertebrates alike, and it is conceivable that seeds of this genus are problematic to work with because they require an unusual set of pretreatment conditions. Consequently, experiments are being carried out to mechanically scarify $V$. phaeantha seeds using the feeding mechanism (mandibles) of the giant Madagascar hissing cockroach (Gromphadorhina portentosa Schaum). Seeds have been fed to these insects in the laboratory, and have been recovered intact from roach frass. An experiment is now being carried out to sow these seeds on artificial media, with and without fungi.

ACKNOWLEDGEMENTS. We kindly thank Timothy J. Bell (Chicago State University), Marlin L. Bowles (The Morton Arboretum), and Scott L. Stewart (University of Florida) for ongoing research collaboration and helpful suggestions. Appreciation is also extended to Lynnaun J.A.N. Johnson, and Anna K. Kirk (Illinois College) for critique of the manuscript.
Literature Cited

Batty, A.L., M.C. Brundrett, K.W. Dixon, \& K. Sivasithamparam. 2006. New methods to improve symbiotic propagation of temperate terrestrial orchid seedlings from axenic culture to soil. Austral. J. Bot. 54: 367-374.

Batty, A.L., M.C. Brundrett, K.W. Dixon \& K. Sivasithamparam. 2006. In situ symbiotic seed germination and propagation of terrestrial orchid seedlings for establishment at field sites. Austral. J. of Bot. 54 : 375-381.

Bowles, M.L. 1983. The tallgrass prairie orchids Platanthera leucophaea (Nutt.) Lindl. and Cypripedium candidum Muhl. Ex Willd.: some aspects of their status, biology, and ecology, and implications toward management. Nat. Areas J. 3(4) : 14-37.

Bowles, M.L. \& T.J. Bell. 1999. Recovery strategies and delisting criteria for Platanthera leucophaea, Asclepias meadii, Lespedeza leptostachya, Dalea foliosa, and Cirsium pitcheri. Report to the Illinois Endangered Species Protection Board, The Morton Arboretum, Lisle, IL.

Bowles, M.L., K.A. Jacobs, L.W. Zettler \& T. Wilson Delaney. 2002. Crossing effects on seed viability and experimental germination of the Federal threatened Platanthera leucophaea (Orchidaceae). Rhodora 104 : 14-30.

Clements, M.A., H. Muir \& P.J. Cribb. 1986. A preliminary report on the symbiotic germination of European terrestrial orchids. Kew Bull. 41 : 437-445.

Currah, R.S., C.D. Zelmer, S. Hambleton \& K.A. Richardson. Fungi from orchid mycorrhizas. In: J. Arditti and A.M. Pridgeon (eds.) Orchid biology: reviews and perspectives, VII (pp. 117-170).

Hartsock, J.J., K.A. Piskin \& L.W. Zettler. 2003. Symbiotic seed germination of two showy terrestrial orchids (Platanthera ciliaris, P. cristata; Orchidaceae) using mycorrhizal fungi. SE Biol. 50 : 149 (abstract).

Ortega-Larrocea, M.P. 2005. Symbiotic propagation and reintroduction of terrestrial orchids in Mexico. Selbyana $26(1,2): 361$ (abstract).

McDonald, K., S. Hopkins, S. Perlman, \& L. Zettler. 2006. The status and propagation of the Federally endangered Hawaiian endemic, Platanthera holochila (Orchidaceae). SE Biol. 53 : 209 (abstract).

Poulter, S.B., K.I. McDonald, S.E. Hopkins \& L.W. Zettler. Seed propagation of rare epiphytic and terrestrial orchids native to Florida (Cyrtopodium, Epidendrum, Habenaria) using a mycorrhizal fungus. $17^{\text {th }}$ Annual Undergraduate Conference, Butler University, Indianapolis, IN, published abstracts (p. 31).

Rangel Villafranco, M. 2006. Germinación simbiótica y reintroducción de orquídeas terrestres en la Reserva Ecológica del Pedregal de San Ángel, México, D.F. Maestra en Ciencias Biologicas, Universidad Nacional Autonoma de Mexico (UNAM).

Rasmussen, H.N., T.F. Andersen \& B. Johansen. 1990. Light stimulation and darkness requirement for the symbiotic germination of Dactylorhiza majalis in vitro. Physiol. Plant. 79 : 226-230. 
Rasmussen, H.N., B. Johansen \& T.F. Andersen. 1989. Density-dependent interactions between seedlings of Dactylorhiza majalis (Orchidaceae) in symbiotic in vitro culture. Physiol. Plant. 77 : 473-478.

Sharma, J., L.W. Zettler, J.W. Van Sambeek, M. Ellerseck \& C.J. Starbuck. 2003. Symbiotic seed germination and mycorrhizae of Federally-threatened Platanthera praeclara (Orchidaceae). Am. Mid. Nat. 149 : 79-95.

Shefferson, R.P., M. Weiss, T. Kull \& D.L. Taylor. 2005. High specificity generally characterizes mycorrhizal association in rare lady's slipper orchids, genus Cypripedium. Mol. Ecol. 14 : 613-626.

Sheviak, C.J. 1974. An introduction to the ecology of the Illinois Orchidaceae. Illinois State Museum Scientific Papers XIV, Springfield, Il.

Sheviak, C.J. \& M.L. Bowles. 1986. The prairie fringed orchids: a pollinator-isolated species pair. Rhodora 88 : 267-290.

Stewart, S.L. 2003. The successful reintroduction of the short-lipped ladies'-tresses to Florida, USA: implications for the future of native orchid restoration. In: Soorae P.S. (ed.) Reintroduction NEWS, No. 22, Newsletter of the IUCN/SSC Reintroduction Specialist Group (pp. 21-22).

Stewart, S.L. \& M.E. Kane. 2006. Symbiotic seed germination of Habenaria macroceratitis (Orchidaceae), a rare Florida terrestrial orchid. Plant Cell Tiss. Organ Cult. $86: 159-167$.

Stewart, S.L. \& M.E. Kane. 2006. In vitro specificity exhibited by fungal mycobionts of Spiranthes floridana (Orchidaceae) within the congener Spiranthes brevilabris. In Vitro 42:37-A (abstract).

Stewart, S.L. \& L.W. Zettler. 2002. Symbiotic germination of three semi-aquatic rein orchids (Habenaria macroceratitis, $H$. quinqueseta, $H$. repens) from Florida. Aquatic Bot. 72 : 25-35.

Stewart, S.L., L.W. Zettler, J. Minso \& P.M. Brown. 2003.
Symbiotic germination and reintroduction of Spiranthes brevilabris Lindley, and endangered orchid native to Florida. Selbyana 24 : 64-70.

Wagoner, C.S., A.L. Stice, S.L. Stewart \& L.W. Zettler. 2002. Seed propagation of Spiranthes cernua (L.) Rich. (Orchidaceae) using mycorrhizal fungi from two genera (Epulorhiza and Ceratorhiza). SE Biol. 49 : 168 (abstract).

Yoder, J.A., L.W. Zettler \& S.L. Stewart. 2000. Water requirements of terrestrial and epiphytic orchid seeds and seedlings, and evidence for water uptake by means of mycotrophy. Plant Sci. 156 : 145-150.

Zettler, L.W. Nature's fungus connoisseurs: new insight into the mysterious orchid-fungal association. Orchids 74(4) : 292-297.

Zettler, L.W. \& T.M. McInnis, Jr. 1992. Propagation of Platanthera integrilabia (Correll) Luer, and endangered terrestrial orchid, through symbiotic seed germination. Lindleyana 7 : 154-161.

Zettler, L.W., S. Perlman, D.J. Dennis, S.E. Hopkins \& S.B. Poulter. 2005. Symbiotic germination of the Federally endangered Hawaiian endemic, Platanthera holochila (Orchidaceae) using a mycobiont from Florida: a conservation dilemma. Selbyana $26(1,2): 269-276$.

Zettler, L.W., K.A. Piskin, S.L. Stewart, J.J. Hartsock, M.L. Bowles \& T.J. Bell. 2005. Protocorm mycobionts of a Federally threatened orchid, Platanthera leucophaea, and a technique to promote leaf formation in seedlings. Stud. Mycol. 53 : 163-171.

Zettler, L.W., S.B. Poulter, K.I. McDonald \& S.L. Stewart. 2006. Conservation-driven propagation of an epiphytic orchid (Epidendrum nocturnum) with a mycorrhizal fungus. HortSci. 42(1) : (in press)

Zettler, L.W., S.L. Stewart, M.L. Bowles \& K.A. Jacobs. 2001. Mycorrhizal fungi and cold-assisted symbiotic germination of the Federally threatened eastern prairie fringed orchid, Platanthera leucophaea (Nuttall) Lindley. Am. Mid. Nat. 145 : 168-175.

Emily E. Massey was raised in Jacksonville, Illinois and is an undergraduate student at Illinois College majoring in Biology. Since 2005, she has participated in projects aimed at the conservation of terrestrial (P. leucophaea) and epiphytic orchids (E. nocturnum). She presented her first research talk last summer at the National Autonamous University of Mexico (UNAM) in Mexico City.

Lawrence W. Zettler earned a BS degree in entomology at the University of Florida (1987), and a PhD in plant physiology at Clemson University (1994). He is an associate professor at Illinois College, a research associate at The Morton Arboretum (Lisle, IL) and Marie Selby Botanical Garden (Sarasota, FL), and a member of the American Orchid Society's Research Committee. He is also a biological illustrator who specializes in color pencil. 